\title{
A Critical Performance of Thom Gunn's "Misanthropos"
}

\section{Merle E. Brown}

If one attends to his own experience of reading poems rather than to that of hearing a poet read poems in a crowded hall, he will, I believe, agree that the performance to which a poem summons him is not so much a public recitation as it is a form of criticism analogous to the performing arts. If the poet is a performing self, as Richard Poirier claims, if no work of art comes alive except in the presence of an audience, as R. G. Collingwood argues, if the reader of poems must accept these claims, nonetheless he will modify them because of his recognition that the poet is always his own first audience. ${ }^{1}$

The echoing quality of all poetic language depends on the presence of this primary audience, on the felt presence of the poet as his own first listener, and this essential echo is drowned out and rendered inaudible by the assumption that the life of poetry depends on its metropolitan audiences which are reached through our great publishing firms and on those crowds who are gathered together by the business of organizing poetry reading circuits. Unless misled by the prospect of a cash reward, no poet would think he was reciting his poems in order that they might be heard. For he could not even compose a poem unless it were heard in the very act of composition. The experience of reading poems to oneself and especially reading them silently must reveal that the listening presence of the poet has to be attended to just as much as his speaking presence. One cannot, in fact, even hear the words of poetry unless he also attends to the echoing into silence which is, at a conceptual level, the poet's act of shaping the poem. A poet works with his words in order to articulate that innermost feeling which determines the quality of his self, his world, and his experience. His words work poetically only in so far as they are the echo of that upsurge of feeling. A reader of those words can respond to them as echoingly resonant only to the extent that he also attends to the echo of that echo, to the overarching action which is the poet's own attending to his words as echoing the deepest impulsion of his experience.

Words working poetically are neither transitive nor intransitive. They do not, like words used practically or intellectually, have the reason for their being in the conventional patterns and structures and frameworks to which they refer, even though they may include such transitive references. Nor are they self-subsistent, only internally referential, elements of an autonomous artifact, a fiction, a sort of

1 See chap. 14 of Collingwood's The Principles of Art (Oxford, 1938) and Poirier's The Performing Self (Oxford, 1971). 
entertaining make-believe. They are rather, in their essential nature, the echo of being as an upsurge of feeling and are in turn echoed by the becoming which is the poet's act of shaping that feeling into an articulated vision.

Quite apart, then, from being read and attended to critically by another person, a poem is itself an active community constituted by the poet as speaker and the poet as listener, by the poet expressing his deepest sense of himself and his world and the poet listening to and criticizing that expression. The poem circles in widening waves, out from its elemental feeling, as the poet speaks listening and, having listened, speaks further until he has exhausted his capacity for composition.

For at least the past twenty-five years, as part of the macadamization of literary studies, critics have been busy crushing out the communal life of the poem by reducing its being and its becoming, its feeling and its thinking, to what I should call its non-being, its status as a self-subsistent object. Once objectified in this way, the poem may then be said to have, in René Wellek's terms, a single structure of determination, the grasp of which leads us to its proper meaning. ${ }^{2}$ Once reduced to an artifact, the poem calls for an interpretation in the manner of E. D. Hirsch, Jr., a delimitation of its intrinsic and extrinsic genres, accomplished by reference to the linguistic ambience of the poem, now treated as an object among objects. With the poem rendered lifeless and the process of interpretation itself doing nothing to revive it, critics have been led unavoidably, in order to retain some sense of themselves as alive, into widening circles of entrapment. Hirsch himself will locate Wordsworth's Intimations Ode within the vast framework of Schelling's philosophy. Raymond Williams, like many another neo-historicist, will view each objectified literary work in the light of a massive social and political movement, his version of which he calls The Long Revolution. Northrop Frye, radical structuralist that he is, will back away from the painting fixed on the wall until it blurs with more and more of its neighbors, "all reduced to one form and one size," to a single structure, a repetition, only, with variations, capped by his favorite myth. With the poem's echoing in widening waves blocked out, the critic must undertake his own spiralling out, with the consequence that the warmth and light of the poem diminishes to the point where it averages out with all other poems in grains of dust. There are, of course, secondary values accruing from such critical strategies. But all rest upon a deepseated error, the conception of the poem as a corpus, the direct touch of which is death. The pain of that touch, or a horror at its numbness, when it should have been so vital, is what set them off on their long slow trips, on which they passed no humans, until each arrived, a final man upon a final hill, in a state of ataraxia, of apatheia, unperturbed by the touch of the dead poem or by any recollection of the joyful pain of touching the living poem.

If we do leave the green slopes of our isolation and vacate the empty centers of our structuralistic, historicistic, phenomenological webs, and approach a

2 Wellek, "Kenneth Burke and Literary Criticism," The Sewanee Review (Spring, 1971), 187-188. 
genuine poem with some sense of its vital activeness, we will find in its smallness an illumined largeness realizing, as few other experiences can, the full being of human community. The experience must surely be a painful one, partly because of our own bad habits, but also because of the painful element in all genuine community. We may even have to learn to memorize poetry again, so that we can truly join our breath with the poet's, giving the poem time to germinate in the dust of our own natures until we feel its deep surge and overarching action. The closer we get to a poem, the more fully we experience the world as it is in the articulation of the poet, the more painful our sense of his otherness from ourselves is almost sure to become. At some point in our attention not just to what the poet says, but also to the way in which he attends to what he says, we will be forced to recognize that neither his mouth nor his ears are ours and, even while at one with the poem, we will move out of it into our own sense of experience in the effort to hear and feel its resonances as distinct from and at times at odds with those of the poem. At this stage, in this concordia discors, at one with the poem and distinct from it, opening up to ourselves our own natures as part of our experience of opening up the innermost nature of the poet and his world, with the poem qualifying and judging us as we qualify and judge it, in this vital interplay we will experience the living pulse of human community as it is and as it might be, but ah, as it is, as it is. And then, at last, we will be ready to perform the poem critically.

It is not possible to work out the critical performance of a poem by means of direct encounter, by what children call a "stare-down," and thus it is that I have moved with indirection toward Thom Gunn's "Misanthropos," in spite of the lines with which Gunn concludes the poem:

\author{
You must \\ If you can, pause; and, paused, \\ Turn out toward others, meeting their look at full, \\ Until you have completely stared \\ On all there is to see. Immeasurable, \\ The dust yet to be shared.
}

Each of the seventeen poems of which "Misanthropos" is composed echoes the others, and all of them interinanimate each other. But if one would sense the surge of feeling that gives life and unity to the whole, he must attend to the interlinking action of Gunn's mind. Just as the final man of the poem, who has become its first man, can affirm that you must "Turn out toward others, meeting their look at full,/ Until you have completely stared/ On all there is to see," only if you have the capacity to pause, so we can stare into these final lines of the poem with understanding only if we can pause to hear the deepest echoes of the whole as they roll up and break into this final affirmation.

The skeletal pattern of "Misanthropos" is not hard to discern nor is discerning it important, when compared to the question, "do these bones live?" But noting 
it has mnemonic value and is a first step in coming as close to the poem as possible. The pattern is derived ultimately from Vico's eternal course and recourse of nations. The decadence of any nation or civilization is a state of disintegration. In the final stage of Rome, the citizens retreat to the hills, each one a final man upon his final hill. The accepted hierarchy of value collapses, each man carries off his own fragmentary version of it to his own hill, no one sees anyone else, and it is only the wind that utters ambiguous orders from the plain. Chaucer's pilgrims may stand as representative of another such recourse of decadence. But such decadence is virtually indistinguishable from the innocence with which a new recourse of nations begins. Thus, as Toynbee has shown, the Holy Roman Empire springs out of the isolated monasteries and mountain citadels and Germanic tribes which represent the final stage of the fall of the Roman Empire. And Chaucer's pilgrims are full of innocent exuberance and self-confidence. Now Gunn, in "Misanthropos," is working with just this moment of transition in the eternal course and recourse of nations, the moment of decadence as it turns into the moment of innocence.

But Gunn responds to this pattern in an extremely personal way. He feels, and I think he is right to feel so, that all his poetry written prior to the volume Touch (The University of Chicago Press, 1967), in which "Misanthropos" is the central poem, was fundamentally decadent. His first volume, Fighting Terms (1954), was written while he was still an undergraduate, and Charles Tomlinson found it to be clever and precious, an adolescent forcing of talent, much as F. R. Leavis had found Auden's early verse to be. ${ }^{3}$ His first poem of that volume, "Carnal Knowledge," begins with the clause, "Even in bed I pose," and includes the line, "You know I know you know I know you know," which should sum up adequately the cleverness and preciosity of the early Gunn.4 In the third poem of "Misanthropos," Gunn as listener recognizes the similarity between the early Gunn and the final man in these lines:

But the curled darling who survives the war
Has merely lost the admirers of those curls
That always lavished most warmth on his neck;
Though no one sees him, though it is the wind
Utters ambiguous orders from the plain,
Though nodding foxgloves are his only girls,
His poverty is a sort of uniform.

Even in isolation he adopts a role and poses. He remains the same as the one who "Curled my hair,/ Wore gloves in my cap." By wearing dark glasses, he was able to stand, "an armed angel among men." He fussed affectedly over the

3 Tomlinson, "Poetry Today," The Modern Age, vol. 7 of The Pelican Guide to English Literature (Penguin, 1963), p. 473.

4 In the three editions of Fighting Terms (1954, 1959, 1962) "Carnal Knowledge" has been much revised. 
question of whether he was spy or spied on, "master,/ or the world's abject servant." I do not intend, by noting these echoes in "Misanthropos" from earlier poems, to suggest that the poem is basically a conversation with those poems. Contrary to the position of Thomas Whitaker, I am convinced that no genuine poem is such a conversation..$^{5} \mathrm{~A}$ poem is essentially a dialectical dialogue between the poet speaking and the poet listening, the poet expressing and the poet criticizing; any conversational echoes with other poems which it may include are strictly subordinate to that primary dialogue. Thus the man referred to in "Misanthropos" as "the curled darling who survives the war," though he resembles a Gunn who could say "Even in bed I pose," is transformed by a feeling of loathing and disgust which is absent from the earlier poem. If it were insisted that the poem is a conversation with another poem outside it, then one would be forced to say that in the poem itself the conversation is fraudulently partisan, and whatever genuine conversation one claimed to exist would be the concoction of the critic rather than the creation of the poet.

When Gunn came to America in 1954 he avoided that deepening of affectation to which Auden succumbed, by going to Stanford and coming under the severe tutelage of Yvor Winters. Once there Gunn peeled off that delicate fastidiousness which would cause Philip Larken to be terrified of riding a motorcycle for fear he might tear his pants. Gunn heard the call, "Man, you gotta Go," and joined the Boys, "In goggles, donned impersonality." It is clear that, in The Sense of Movement (1957), Gunn does not "strap in doubt," as the Boys do, but the last lines of "On the Move,"

At worst, one is in motion; and at best,

Reaching no absolute, in which to rest,

One is always nearer by not keeping still.

indicate that, for all his doubt, for all his knowledge that the Boys are "Small, black, as flies hanging in heat," he can come up with no alternative to riding in the "direction where the tires press," and thus accepts their way even though with a despairing cynicism. The passage echoing "On the Move" in the fifth poem of "Misanthropos" is dominated by a quite different feeling:

$$
\begin{aligned}
& \text { thickets } \\
& \text { crowd in on the brown earth gap } \\
& \text { in green which is the path made } \\
& \text { by his repeated tread, which, } \\
& \text { enacting the wish to move, } \\
& \text { is defined by avoidance } \\
& \text { of loose ground, of rock and ditch, } \\
& \text { of thorn-brimmed hollows, and of } \\
& \text { poisoned beds. The ground hardens. }
\end{aligned}
$$

5 Whitaker, "Voices in the Open: Wordsworth, Eliot, \& Stevens," The Iowa Review (Summer, 1971), 96-112. 
Bare within limits. The trick

is to stay free within them.

The path branches, branches still,

returning to itself, like

a discovering system,

or process made visible.

Here Gunn places the despairing cynicism of his decadence with a fine, discriminating disgust. The Boys were really just going around in circles. And their act was craven. Like our master structuralists, concocting patterns as remote as possible from the thickets of genuine poetry, they treaded out their discovering systems, returning upon themselves, merely to avoid the fearful things moving at the edges of their minds. Nor is there, in "Misanthropos," any of that sentimental indulgence with which "Lines from a Book" closes:

I think of all the toughs through history

And thank heaven they lived, continually.

Gunn has achieved that moral discrimination of which Leavis despaired in Auden and which Tomlinson feared Gunn would not attain.

He has even surpassed the hard heroizing of the title poem of his next volume, My Sad Captains (1961):

who, I thought, lived only to

They were men

renew the wasteful force they

spent with each hot convulsion.

They remind me, distant now.

True, they are not at rest yet, but now that they are indeed apart, winnowed from failures, they withdraw to an orbit and turn with disinterested hard energy, like the stars.

As early as the fourth poem of "Misanthropos," Gunn recognizes that such heroes are modelled on the movement of the moon ("And steady in the orbit it must go.") and the Milky Way ("A luminous field that swings across the sky,") and that they represent an "envy for the inanimate." In the fourteenth poem, the first man's desire to be "Inhuman as a star, as cold, as white,/ Freed from all dust" is placed as a form of cowardice, an unwillingness to accept the dust of life itself. Yvor Winters complained that the Gunn of A Sense of Movement and My Sad Captains usually had a "dead ear."6 If his own sense of experience had not been so close to that of Gunn's, Winters might have realized, as Gunn does in "Misanthropos," that the deadness went much deeper than the ear.

6 Winters, Forms of Discovery (Swallow, 1967), p. 345. 
It was not, however, the Viconian pattern or Gunn's personalization of that pattern which sprung him free of his deadness, but rather, I think, his discovery that his decadence was "wholly representative." Gunn makes that recognition throughout "Misanthropos." His withdrawal first into affectation and then into isolated hardness ran parallel to a mass reaction to the Second World War. When the relief of the end of the war had exhausted itself, men turned away from each other in disgust. The humanized air which held the nation together in its united war effort suddenly became dry and empty. Even hitchhikers were abandoned to themselves. "Each colourless hard grain" was "now distinct,/ In no way to its neighbour linked." College students writing essays about what sort of man they would like to have survive a nuclear holocaust were in truth working out the desire to be "The final man upon a final hill." It was not their fear of the future but their disgust for the past which made them open this "disused channel/ to the onset of hatred." Nor was the hysterical construction of fall-out shelters, an act usually accompanied by an image of oneself gunning down his improvident neighbors who implored him for a breath of unpoisoned air, really a sign of providence so much as it was an expression of misanthropy, a dream in which one was at last free of the smudge of other men. Some such realization resounds throughout "Misanthropos": we had all withdrawn into an isolated state of ataraxia where we could live imperturbably, untouched by pain, "evil's external mark," unaware that if pain is the mark of evil, it is also the mark of goodness, the mark of "A man who burnt from sympathy alone."

That Gunn could find a way out of such a state, in which he had "grown/ As stony as a lizard poised on stone," is not so remarkable as it might at first appear, especially to Americans. For, unlike us, he had behind him an experience in England following upon the First World War much like what happened to us only after the Second. Think, for example, of Yeats' ataraxic "An Irish Airman Foresees His Death" or of his desire to be taken up in the stone mosaics of Byzantium. Think too of Ezra Pound's major English poem, "Hugh Selwyn Mauberley," a poem written out of a state of paralysis from which there seemed to be no exit, whether into a Pre-Raphaelite dreamworld or into an impossibly depraved society run by the Mr. Nixons. Or consider whether the most influential English poem of the century, Eliot's Four Quartets, is not in truth written out of a deep state of ataraxia, being the sustained and repeatedly realized withdrawal from earthly, engaged experience, even a withdrawal from the crumbling language of the poem itself. Once Eliot had abandoned personal, sexual love in the poem "La figlia che piange," mustn't he be viewed as the exemplary final man upon the final hill, for whom every personal face is but a mask beyond which one moves into "the still point of the turning world"?

Even more important to the change that takes place for Gunn in "Misanthropos" is the criticism of F. R. Leavis and of the journal Scrutiny, which was a focus of literary intelligence in England from 1932 to 1952. Nothing in American criticism is comparable to Leavis' battle against the disintegration of 
his society and the impersonalization of both its social experience and its art. Leavis fought these heavy driftings not from the outside, rebelliously and violently, but from within, burning with good will and sympathy. He has never, for example, reneged on his claim that Eliot is one of the greatest of English poets. Compare his cautious and tentative and delicate criticism of Eliot with the blasts of Yvor Winters or with Quentin Anderson's recent claim, bordering as it does on hysteria: "The notion of the impersonality of art became the refuge of the infantile demand to rule the whole world."7 Anderson's immediate targets are Emerson, Thoreau, Whitman, and Henry James, and the hundreds of thousands who gathered at Woodstock. But he is being exacerbated by the hidden foe of foes, T. S. Eliot. At least when set beside Leavis, Anderson seems to have no capacity to pause, and, having paused, to turn out toward others. In spite of himself, he appears as one more imperial self raging against imperial selves. Whereas for over thirty years Leavis did what Matthew Arnold tried to do but could not: by the free play of his mind, with his ideas of great poetry as both personal and impersonal and his conception of an English tradition as embodying such excellence, he made possible the recent resurgence of English poetry, among the finest representatives of which, in addition to Gunn, are Donald Davie, Jon Silkin, and Charles Tomlinson. Not, of course, that Gunn has found the way out of his stony isolation simply by following Leavis' precepts. He is an original poet, and, for all the resemblances between his recent poetry and the ideals Leavis advocates and certain poems by Davie, Silkin, and Tomlinson, the beating impulsion and the curve of action of "Misanthropos" are distinctly Gunn's own.

Even so, if Gunn had not had in his background Leavis' opposition to the impersonality and self-abnegation of Eliot, it seems likely that he would have fallen under the spell of that peculiarly imperialistic form of misanthropy to be found in so much of the very finest of contemporary American poetry. He could easily have turned into the path of Robert Bly, as James Wright did, temporarily, and tried to abandon his keen intellect and self-awareness. Bly would have us abandon ourselves utterly in order to move to the deepest point of our brain, where it dissolves into oneness with the God in Nature. He would have us move back to that still point at the heart of the wilderness and live and write poetry out of that impersonal center. Or Gunn might have followed Gary Snyder beyond the high point of his mountain retreats into an oriental form of ataraxia. At the very least he would have fallen in with Allen Ginsberg's feeling that "All separate identities are bankrupt." Without Leavis' constant warnings he would have missed the odd likeness between the violence at the center of the vision of those poets who reject our society and the destructive acts committed in the name of that society. He would have missed the similarity between the perspective those poets take on the society they reject and the perspective of that society on the basis of which its leaders make it move.

With all his misanthropy and with all the sympathy he shows for this Ameri-

7 Quentin Anderson, The Imperial Self (Knopf, 1971), p. 203. 
can form of misanthropy, Gunn is able to resist this deepest revulsion for men with a disgust more intense than the sympathy he feels for it. Gunn articulates this complex mixture of sympathy and disgust in the twelfth poem, "Elegy on the Dust," which is the high point of "Misanthropos," the point at which the last man turns into the first man. The poem is a stunning articulation of the vision of men in society as a bowl of dust, "vexed with constant loss and gain," "a vaguely heaving sea," a graveyard which is a sea of dust. At the beginning of "Misanthropos," the final man was being a contemporary Englishman in his refusal to build a watch tower. But here he has moved to America and looks outward from his retreat, taking into his view the hill, the wooded slope, and the vast expanse of dust beyond it. He has made the transfer which Lawrence's Lou Witt makes at the end of "St. Mawr."8

"Elegy on the Dust" ends with this visionary judgment on man in a modern mass nation state:

Each colourless hard grain is now distinct, In no way to its neighbour linked,

Yet from wind's unpremeditated labours

It drifts in concord with its neighbours,

Perfect community in its behaviour. It yields to what it sought, a saviour:

Scattered and gathered, irregularly blown, Now sheltered by a ridge or stone,

Now lifted on strong upper winds, and hurled

In endless hurry round the world.

The poem might seem to be merely a vision of man's ultimate form of decadence, that last stage in a Platonic cycle of degeneration at which a mobocracy turns into tyranny. Men are seen in the poem at their very lowest, averaged out in indistinguishable "grains of dust/ Too light to act, too small to harm, too fine/ To simper or betray or whine." In such a mobocracy, where even those who sought distinction hard are levelled with the rabble, in absolute uniformity, men are ready for a savior, a tyrant, who will windily hurl them "In endless hurry round the world." But instead of sharing this vision of Marcuse of the complete bankruptcy of our civilization, Gunn attends to its articulation with his keen, critical ear and turns the poem into a condemnation of that vision for which he has so much sympathy. The ultimate form of decadence turns out to be not what is seen, but the vision itself. As Raymond Williams has argued so persuasively, men exist as a mass only in the eye of the beholder. It is the beholding of men as a bowl of dust, as a mobocracy turning into a tyranny, not the men beheld in such a way, which is decadent.

One senses the special judgmental turn which Gunn is giving the vision in the way he works certain allusions into the poem. For example, in this part of the second stanza:

\footnotetext{
8 See Poirier's superb analysis of "St. Mawr" in A World Elsewhere (Oxford, 1966), pp. $40-49$.
} 
Beneath it, glare and silence cow the brain

Where, troughed between the hill and plain,

The expanse of dust waits: acres calm and deep,

Swathes folded on themselves in sleep

Or waves that, as if frozen in mid-roll

Hang in ridged rows.

Gunn is clearly echoing Wordsworth, and especially in the "acres calm and deep" the line "Ne'er saw I, never felt, a calm so deep!" from the sonnet "Composed upon Westminster Bridge." But he is doing more than simply alluding to the line; he is also judging Wordsworth's vision of London as organically beautiful only when all its citizens are asleep as an expression of imperialistic misanthropy. With Wordsworth so deeply studied and felt, Gunn could not fail to recognize the way in which the viewer personally determines the nature of the view. That the line "And vexed with constant loss and gain" in the next stanza echoes Wordsworth's sonnet "The world is too much with us" simply confirms how Gunn has learned from but then gone beyond the poet whom Galway Kinnell is now echoing somewhat uncritically. Of course, Marvell is present too, especially in the allusions to his most misanthropic and misogynous poem, "The Garden," as the lines "Interdependent in that shade" and "Are all reduced to one form and one size" echo the lines "Annihilating all that's made/ To a green thought in a green shade." But the dominant allusion of the second of Gunn's lines just quoted is to Pound's "Hugh Selwyn Mauberley."

here

The graveyard is the sea, material things

-From stone to claw, scale, pelt and wings-

Are all reduced to one form and one size

echo these lines from Pound's "Envoi":

I would bid them [the woman's graces] live

As roses might, in magic amber laid,

Red overwrought with orange and all made

One substance and one colour

Braving time.

Gunn senses that Pound's advocacy of the eternal beauty of art over the transiency of ordinary experience, summed up as it is as "Siftings on siftings in oblivion," is just a step short of going off to Italy and becoming an advocate of the Duce. It is Gunn's disgust for this disgust for men in society that turns the "Elegy on the Dust" away from being just one more imperial vision and into an extremely personal expression of Gunn's revulsion for such imperialism. It is the vision of men as a smudge of dust, this way of seeing men, which must be buried, the reducing of men to such a state, not men thus reduced, which must be abandoned. Gunn knows too much about Pound, he knows what Leavis 
recognized in him and what Donald Davie, following Leavis' lead, demonstrated in his book Ezra Pound: Poet as Sculptor, to be willing to follow after Ginsberg, Snyder, and Bly.

My reading of the "Elegy" as an expression of disgust for the vision of men as a bowl of dust instead of as a direct expression of that vision is reinforced by echoes in the "Elegy" from the poem just before it, the Epitaph for Anton Schmidt, and by the echoes of the "Elegy" itself in the poem which follows it, "The First Man." There is no irony in Gunn's admiration for Anton Schmidt, whose greatness depends on his not having mistaken "the men he saw,/ As others did, for gods or vermin." The vision of the "Elegy" clearly mistakes the men viewed for vermin and the viewer for a god. Furthermore, the first man of the 13th poem is presented as Gunn's vision of the man who has had the vision of the "Elegy," "An unreflecting organ of perception." That man can perceive men as a disgusting smudge because he does not reflect on what such a vision implies about himself. What it implies for Gunn is that, just as the men viewed in the "Elegy" disappear into the dust of a society blown "In endless hurry round the world" by a windy tyrant, so the visionary of the "Elegy," that imperial self, that "transcendental eyeball," is finally to be seen "darkening in the heavy shade/ Of trunks that thicken in the ivy's grip." And this image of the first man, of this American innocent, this barbarian who may be what must follow after the decadence of Europe, this appalls Gunn as much as it did the poet here being echoed, Wallace Stevens. The 11th poem of Stevens' "The Man With The Blue Guitar" is the rejection of its vision of men dissolving into a thicket of time, where they are caught as flies, "Wingless and withered, but living alive." At this point Gunn must make his final choice: to accept the disappearance of man as an individual into the dust of society or the heavy shade of nature or to reaffirm the value of that man as distinctive. His choice, as is obvious from the 14th poem, is the second: he must stare upon men as a smudge until they come so close to him that the outlines of the smudge break away from it and the men turn into individuals.

Only as a result of doing this does he realize in direct experience that as he gazes upon a man, he is himself gazed upon, as he touches another, he is himself touched, and that his own self and his whole world are enlarged and enlivened by this interaction. Gunn does not simply assert this but works it out experientially by means of echoes. The first man's affirming in the 17th poem that you must pause, if you can, echoes and is even learned from the scratched man's pausing in the 16th poem. The first man's revulsion from the stale stench, the hang-dog eyes and the pursed mouth of the scratched man in the 16th poem echoes the scratched man's response to the first man when he first sees him in the 15th poem:

The creature sees him, jumps back, staggers, calls, Then, losing balance on the pebbles, falls.

The effect of Gunn's restraint in this passage-we aren't quite sure what the lines imply and may even feel them to be empty-is that our sense of the re- 
pulsiveness of the first man and Gunn's sense of his own repulsiveness coincide with the first man's momentary revulsion from the scratched man even as he grips his arm. Although Gunn's movement out of isolation at the end of "Misanthropos" includes such moments of felt insight, it is harsh and painful. There is no moment of explosive joy as there is at the end of Stevens" "Esthétique du Mal," when Stevens realizes that human life is made up of

So many selves, so many sensuous worlds, As if the air, the mid-day air, was swarming With the metaphysical changes that occur, Merely in living as and where we live.

Gunn's use of the word "stared" to express the way in which we must connect with others suggests harshness. And his last words, "Immeasurable/ The dust yet to be shared" come out with a grudging sigh. But Gunn has made his recognition and affirmation. And the poems which follow "Misanthropos" in Touch, especially the last one, "Back to Life," and many poems in his most recent volume, Moly, show that he meant it.

The innermost sense of experience which forces Gunn to pull himself out of his isolation still remains to be explained. What forces him to affirm the value of human community is, I believe, his sense that his own nature as an individual is communal, even when he is most isolated. Observing the first man, in the 13th poem, "darkening in the heavy shade/ Of trunks that thicken in the ivy's grip," he sees that his very existence as an individual, composed of himself as self-aware observer and himself as a rudimentary man, is about to be annihilated. It is his commitment to himself as a community, as both spy and spied on, which forces him finally to turn out toward others. The final choice is between dissolving into nature and rejoining men. Gunn chooses the second because of his growing awareness that the very essence of himself as an individual is communal and that he will not survive in any form at all if he becomes one with nature.

As early as the second poem of "Misanthropos," Gunn reveals the doubleness of his individuality as poet and the last man quite emphatically. In contrast to the first poem of the sequence, in which Gunn as poet talks out his sense of himself as the last man, presented in the third person, in the second poem Gunn speaks as the last man in the first person to his echo, which of course is Gunn as poet. This conversation concludes thus:

Is there no feeling, then, that I can trust, In spite of what we have discussed?

Disgust.

The form of the whole of "Misanthropos" is implicit in these lines. The experience of the last man is based upon disgust, upon misanthropy. But the nature of this disgust is articulated in marvellously varied discussions carried on between the last man and his echo or, to reverse the coin, between Gunn 
as poet and himself as last man. Gunn's shifting from poem to poem between the last man as objectively third person and as subjectively first person can be explained in no other way. It is in passing through "what we have discussed" that Gunn is enabled to move from disgust to trust and thus begin the last poem with:

Others approach. Well, this one may show trust Around whose arm his fingers fit.

The trust of this last poem never breaks free from a need that it be discussed or even, for that matter, from an element of disgust. Thus, the poet, in expressing the last-man-become-first-man's willingness to trust the scratched man, also implies his grave doubts as to whether the man is worthy of such trust. Even the internal community of the second poem, moreover, is itself full of disgust. To get the tone of the poem right one needs to add to each echoing word the phrase "you poor fool." Thus, even though the basic movement of "Misanthropos" is from isolated disgust through discussion to communal trust, there is an internal community involved in the initial disgust just as there is an element of disgust in the trust of the final external community.

Once the reader recognizes the explicitly communal nature of the isolated individual as presented in the second poem, he can then see this community as implicitly present even in the first poem, which begins:

He avoids the momentous rhythm

of the sea, one hill suffices him

who has the entire world to choose from.

He melts through the brown and green silence

inspecting his traps, is lost in dense

thicket, or appears among great stones.

Although one probably begins the poem merely spying on the last man, who "lives like/ the birds, self-contained they hop and peck," further readings are sure to convince him that the poem contains, along with the man we spy on, its own spy, the echoing, controlling presence of the poet. Unlike the last man, the last man's echo, the poet Thom Gunn, proves himself capable of the momentous rhythm of the sea. The first clause of the poem, with its anapestic rhythm and with the first line running on into the second is a sea-like rhythm. But having set this rhythm in motion, the poet then drops it abruptly, with the second clause, "one hill suffices him," working iambically and in a syntax at odds with that of the first clause, so that there is no build-up by way of clauses rhythmically and syntactically parallel. Similarly, in the second stanza the first line is a return to the momentous rhythm of sea-like anapests, but here the expected run-on effect of the first stanza is frustrated; one must pause after "silence" and begin again with "inspecting his traps." The poet as spy does, in other words, have a watch tower. He is not self-contained as the 
spied-upon man is; he looks beyond that self-containment to glimpse the rhythm the last man avoids, introducing it only to break it down, so that we sense not just the isolation of the man, but also that from which he is isolated.

The communal nature of "Misanthropos" is shared, it seems to me, by all genuine poems, and is why John Crowe Ransom was wrong when he said: one cannot write a love poem while he is in love and that is why Elizabeth Barrett Browning's sonnets are loving but unpoetic. The truth is rather that one must be both in love and out of love to write a love poem. To write a poem on himself as a man who widens his solitude till it is absolute, Gunn had to be both in that solitude and in community. In other words, the very writing of the poem forces him into internal communal relations which work against his desire for absolute solitude. "Misanthropos" is distinctive because it is a genuine poem based upon the realization of the communal doubleness inherent in all poetic sincerity. The very form of the poem, the way its parts echo each other, grows out of Gunn's sense that the poet's individuality, in the act of composing the poem, is communal. And it is this sense of the communal nature of the poet as individual, even when pushed to an extreme isolation by disgust, which leads Gunn to reject the American desire for dissolving into nature and to turn out toward other human beings.

Gunn's "Misanthropos" has a cinematic counterpart in Antonioni's Zabriskie Point. Like Gunn, Antonioni explored with fascination our desire to be "on the move" and to throw ourselves into simple, bodily love affairs, and he found them to be expressive of the deeper desire to end up in "this universal knacker's yard," at point zero, all levelled in dissolute copulation on the desert. Though Antonioni draws back from this lure to dissolution, the vision he moves back to is very much like the imperially decadent vision of Gunn's "Elegy on the Dust." This explains, I think, why Zabriskie Point disgusted its American audiences but was extremely popular in Europe. Gunn, in contrast, rejects not just the "vaguely heaving sea" of dust which is America seen from a final hill, but also the vision itself, as a deeper form of decadence than that which it contains and repudiates. Even so, Gunn's final position is not so very stirring. "Misanthropos" is pitched at a thin high extreme of self-consciousness. It is clear that the man who wrote this poem is the same man who wrote "The Corridor," in which the "I" spies through a keyhole at two people making love and then realizes that he the spy is himself being spied upon by a figure in a mirror at the end of the hall. But though the poem is resolutely self-conscious, it does move with the force of necessity beyond itself and into communion with others, whose otherness is more painful and also more vital than the otherness contained within the poet's individuality. The community achieved is minimal, but it is also essential.

One cannot leave the poem without a glancing reminder of what it implies about the critical maneuvers that have been so popular during the past twentyfive years. Once the poem is taken into the blood stream, wouldn't a critic be too ashamed to wear dark glasses and, "Between the dart of colours" to wear a darkening and perceive "an exact structure,/ a chart of the world"? Too many things are moving "at the edges of the mind" to leave him content to be 
treading out a path "like/ a discovering system,/ or process made visible." Nor, once he has watched with Gunn's disgust the paradisal

\author{
cells swimming in concert \\ like nebulae, calm, without effort, \\ great clear globes, pink and white.
}

is he likely to be satisfied with utopian and visionary criticism or, like Harold Bloom, to condemn Yeats' "Sailing to Byzantium" on the grounds that it fails to achieve oneness with the visionary company. ${ }^{9} \mathrm{He}$ would recognize that Yeats' poem comes alive just because the visionary company, the "great clear globes," and the ladies of Byzantium are violated by "the intruder with blurred outline" who touches and holds "in an act of/ enfolding, possessing, merging love." The intruder may cause pain like a devil, but, without such a spark of fire, even sympathy cannot burn.

Criticism that moves to touch and hold a poem will be not only interpretive, but also appreciative. Interpretation alone is more like memorizing notes than performing them. A musician does not try simply to get the notes right. $\mathrm{He}$ must play in such a way as to articulate the living value of the notes, to realize, far beyond the score itself, the vital act of sound in movement which is the composer's creation. It is true, of course, that a critical performance lacks the immediacy of a musical performance. For the critic and his audience must always return to the text of the poem itself and work out the values in it which the critic can at best only hint at and point toward. Even so, I agree with Roger Sessions that, in their purpose and value, literary criticism and musical performance are fundamentally the same. ${ }^{10}$ What the critic may learn from the musician is that he can expose and evoke a poem with any fullness only if he is willing to evoke and expose himself at the very same time. The critic who fashions for himself a frock from the skins of mole and rabbit, who writes in hiding, with sovereign impersonality, who tries to interpret and appreciate a poem in such a way that the poem is not permitted in turn to interpret and judge him, will touch neither the poem nor himself. He must listen long and carefully not just to the poem but also to himself until he too speaks with a voice of his own, if he would ever hope to converse with the intimate dialogue that every genuine poem is. He can learn from the musician that he himself must venture creatively if he would hope to touch the creativity of the poems of his concern. I am not suggesting that schools of criticism should model themselves on the great conservatories. But to the extent that those conservatories are committed not to technical perfection, but to a form of performance in which one realizes himself in the very act of evoking the living composition in all its otherness, it does seem to me that they provide a vital and meaningful model worthy of our emulation. ${ }^{11}$

9 Harold Bloom, Yeats (Oxford, 1970), pp. 344-349.

10 See chap. 3 of Roger Sessions, Questions About Music (Harvard, 1970).

11 The antagonism of Hindemith against performers, expressed in chap. 7 of his $A$ 


\section{AUTOBIOGRAPHY}

The sniff of the real, that's

what I'd want to get

how it felt

to sit on Parliament

Hill on a May evening

studying for exams skinny

seventeen dissatisfied

yet sniffing such

a potent air, smell of

grass in heat from

the day's sun

I'd been walking through the damp

rich ways by the ponds

and now lay on the upper

grass with Lamartine's poems

life seemed all

loss, and what was more

I'd lost whatever it was

before I'd even had it

a green dry prospect

distant babble of children

and beyond, distinct at

the end of the glow

St Pauls like a stone thimble

longing so hard to make

inclusions that the longing

has become in memory

an inclusion

Thom Gunn

Composer's World (Harvard, 1952), stems from his feeling that they try to impose themselves dramatically to the neglect of the composer's creation. A similar danger can be seen in the kind of criticism which Walter Slatoff advocates in his otherwise impressive With Respect to Readers (Cornell, 1970). 